\title{
UNDANG-UNDANG PEMELUKAN ISLAM DI MALAYSIA
}

\section{Law on Conversion to Islam in Malaysia}

\author{
Siti Adibah Abu Bakar ${ }^{1}$ \\ Siti Zubaidah Ismail ${ }^{2}$
}

\begin{abstract}
In recent years, questions have been raised involving welfare and education of converts in Malaysia particularly on how they are managed by the religious authorities and whether there is sufficient resources to assist with their needs. The aim of this article is to study the existing legislation relating conversion into Islam in Malaysia. All states' provisions are examined using descriptive method. It is found that specific provisions on conversion into Islam under the enactment of administration of religion of Islam are available though there are some differences on certain matters. Even so, the standard four main elements are registration procedures, obligations, rights of converts and the status of the children of converts. The study also found that even these matters were allocated in the state provisions, they are still insufficient to solve certain problems facing the converts. Some
\end{abstract}

\footnotetext{
1 Ph.D Candidate, Department of Shariah and Law, Academy of Islamic Studies, University of Malaya, adibah abk@yahoo.com

2 Senior Lecturer, Department of Shariah and Law, Academy of Islamic Studies, University of Malaya, szubaida@um.edu.my
} 
recommendations are highlighted to improve the management of the converts.

Keywords: converts, conversion to Islam, Islamic law, religion

\section{PENDAHULUAN}

Dewasa ini, penduduk Islam di Malaysia bukan lagi hanya terdiri daripada kalangan penduduk berbangsa Melayu dan imigran Muslim dari negara luar sahaja. Bahkan, komposisi tersebut juga turut mengambil kira jumlah orang yang baru memeluk Islam, atau dikenali sebagai mualaf. Menurut rekod yang dikeluarkan oleh pihak Jabatan Kemajuan Islam Malaysia (JAKIM), terdapat peningkatan jumlah mualaf dari tahun ke tahun iaitu sebanyak 106,747 orang, mengikut jumlah terkumpul dari tahun 2000 hingga 2012. ${ }^{3}$ Dalam kita berbangga dengan angka yang banyak ini, wujud juga laporan akhbar yang mengaitkan mualaf dengan perkara negatif. Antaranya seperti isu kemiskinan, wujud mualaf yang pergi mendapatkan bantuan di gereja beberapa tahun yang lalu dan isu permohonan keluar dari agama Islam dalam kalangan mualaf. ${ }^{4}$ Apa yang menjadi kebimbangan di sini, antara faktor yang menyebabkan permohonan keluar dari agama tersebut dibuat adalah kerana berlakunya penceraian dengan pasangan, kurang bimbingan dalam pengamalan ajaran agama sepanjang pengislaman dan sebagainya. ${ }^{5}$

Sebagai seorang yang baru mengenali Islam, setiap aspek kehidupan mualaf, bermula dari sebelum hingga selepas mereka memeluk agama Islam, hendaklah dibimbing mengikut garis panduan Syarak supaya kelangsungan

$3 \quad$ Ikhwan Ng, 'Malaysia Reverted Muslim Statistic,' laman sesawang lifemualaf, http://lifemualaf.blogspot.my/2013/07/malaysia-reverted-muslim-statistic.html, 24 Julai 2013.

4 Sinar Harian, 'Mualaf Hilang Sumber Pendapatan,' laman sesawang Sinar Harian, http://www.sinarharian.com.my/edisi/johor/mualaf-hilang-sumberpendapatan-1.492782, 4 Mac 2016; Berita Semasa, '(Eksklusif) Laporan Penuh JAIS Berhubung Serbuan Gereja,' laman sesawang Berita Semasa, http://www. beritasemasa.com.my/isu-gereja-murtad, 4 Ogos 2011; Lihat juga Blog MIK, 'Isu Serbu Gereja! Ada Mualaf Miskin Terima Bantuan dari NGO Bukan Islam,' laman sesawang Blog MIK, http://medan-info-kita.blogspot.my/2011/08/isuserbu-gereja-ada-mualaf-miskin.html, 8 Ogos 2011; Norain Saleh, 'Mufti: Ramai Mualaf Yang Pohon Murtad,' laman sesawang MalaysiaKini, www.malaysiakini. com/news/167179, 17 Jun 2011.

$5 \quad$ Pg Ismail Pg Musa dan Siti Zubaidah Ismail, 'Permohonan Keluar Islam: Kajian Kes di Mahkamah Tinggi Syariah Negeri Sabah,' Jurnal Syariah, vol. 23/no. 1 (2015): 55 . 
hidup sebagai seorang muslim baru tidak terabai. Justeru, penggubalan sebarang peraturan atau undang-undang bagi mengurus perihal mualaf di Malaysia bukanlah sesuatu yang boleh dipandang ringan oleh pihak berkuasa. Peruntukan undang-undang yang lengkap dan menyeluruh dapat membantu pengurusan hal-ehwal mualaf dengan lebih bersistematik. Bukan itu sahaja, ketidakseragaman perundangan yang terpakai bagi mualaf di negeri-negeri juga seharusnya tidak menjadi permasalahan bagi mencapai matlamat tersebut. Persoalannya, apakah bentuk dan kandungan peruntukan undangundang pemelukan Islam di seluruh negeri di Malaysia, memadaikah ia dalam memelihara kebajikan saudara baru dan dapatkah ia menyelesaikan permasalahan umum yang sering melanda golongan mualaf di Malaysia. Kajian ini menganalisis peruntukan undang-undang yang telah sedia ada di setiap negeri di Malaysia. Menggunakan pendekatan normatif-juridikal, setiap peruntukan berkaitan dikaji dan dimana relevan, contoh kes juga dikemukakan. Pada akhirnya, suatu kesimpulan dan saranan penambahbaikan dikemukakan khususnya kepada pihak berkuasa agama Islam negeri.

\section{SEPINTAS LALU MENGENAI MUALAF DI MALAYSIA}

"Mualaf" berasal daripada perkataan bahasa Arab; muallafati qulubuhum ${ }^{6}$ yang bermaksud 'yang dilembutkan hatinya'. Jika dirujuk kepada kitab-kitab kontemporari, terdapat perbahasan yang mendalam mengenai erti orang yang dijinakkan hatinya untuk mendampingi Islam. Undang-Undang Pentadbiran Agama Islam Negeri juga memberikan definisi mualaf. Sebagai contoh di Selangor dan negeri-negeri lain, mualaf didefinisikan sebagai seorang yang baru memeluk agama Islam menurut Enakmen tersebut. ${ }^{7}$ Mengikut kelaziman masyarakat, orang yang baru memeluk agama Islam, bukan sahaja dikenali sebagai mualaf, malah gelaran saudara baru ataupun saudara kita juga digunakan supaya dapat mendekatkan lagi tautan kasih sayang sesama Muslim di negara ini. Mualaf di Malaysia adalah terdiri daripada pelbagai kaum (selain Melayu) $;{ }^{8}$ iaitu Cina, India, kalangan kaum Orang Asli dan Bumiputera di Sabah dan Sarawak serta lain-lain lagi. Kepelbagaian latar belakang ini secara tidak langsung menimbulkan semangat kepuakan yang harus diharmonikan sebagai penganut akidah yang sama iaitu Islam.

$6 \quad$ Merujuk kepada firman Allah S.W.T dalam Surah al-Tawbah ayat 60. Dalam ayat tersebut, mualaf adalah merupakan salah satu daripada lapan asnaf yang boleh menerima zakat.

7 Seksyen 2, Enakmen Pentadbiran Agama Islam (Negeri Selangor) 2003.

8 Menurut Perkara 160, Perlembagaan Persekutuan, Melayu adalah didefinisikan sebagai orang yang beragama Islam. 
Seiring dengan peningkatan jumlah saudara baru seperti yang disebut di atas, ternyata isu negatif yang timbul berkenaan mualaf juga semakin meningkat dan patut dipandang serius. Selain masalah peribadi seperti pengamalan agama, kewangan serta keluarga, wujudnya pengabaian oleh pihak yang seharusnya menguruskan hal-ehwal mualaf juga turut menjadi titik tolak dalam menambah parah permasalahan mualaf yang telah sedia ada. ${ }^{9}$ Bagi tadbir urus golongan mualaf di Malaysia, terdapat beberapa peruntukan undang-undang di setiap negeri, yang dibincangkan selepas ini.

\section{ASAS UNDANG-UNDANG PEMELUKAN ISLAM DI MALAYSIA}

Malaysia merupakan sebuah negara Persekutuan; ${ }^{10}$ iaitu sebuah negara yang padanya terdapat sebuah kerajaan pusat yang mempunyai bidangkuasa tertentu dan kerajaan negeri selaku ahli persekutuan juga mempunyai bidangkuasa tertentu. Kuasa antara kedua-dua kerajaan tersebut ditentukan pembahagiannya dalam Perlembagaan Persekutuan. ${ }^{11}$ Selepas Malaysia mencapai kemerdekaan, Perlembagaan Persekutuan adalah undang-undang utama negara. Perlembagaan mengandungi peraturan dan dasar pemerintahan negara serta dijadikan asas kepada semua perundangan yang telah sedia ada ataupun yang akan digubal. Mana-mana perundangan yang didapati bercanggah dengan Perlembagaan Persekutuan adalah dengan sendirinya terbatal pada mana-mana peruntukan yang bercanggah tersebut. ${ }^{12}$

Dengan itu, bagi meneliti pembahagian kuasa perundangan antara kerajaan pusat dan kerajaan negeri, Perlembagaan Persekutuan ${ }^{13}$ telah memperuntukkan bahawa Parlimen mempunyai bidang kuasa untuk membuat undang-undang bagi mana-mana bahagian Persekutuan, iaitu terhadap perkara-perkara yang terdapat di dalam Senarai Persekutuan atau Senarai Bersama. Manakala Badan Perundangan Negeri pula adalah berbidangkuasa untuk membuat undangundang bagi keseluruhan atau mana-mana bahagian negeri tersebut sahaja, iaitu terhadap perkara-perkara yang terdapat di dalam Senarai Negeri atau Senarai Bersama.

9 Mohd Ridhuan Tee Abdullah, Cabaran Saudara Baru di Malaysia (Kuala Lumpur: Utusan Publications \& Distributors Sdn Bhd, 2012), 35.

10 Hairol Anuar Mak Din, et al, Kenegaraan Malaysia (Selangor: Penerbitan Imtiazul Ilmi Sdn. Bhd, 2011), 198.

11 Tun Mohd, Salleh Abbas, Prinsip Perlembagaan dan Pemerintahan di Malaysia (Kuala Lumpur: Dewan Bahasa dan Pustaka, cet. 3, 2006), 5.

12 Perkara 4, Perlembagaan Persekutuan.

13 Perkara 73, 74 dan Senarai I,II dan III, Jadual Kesembilan, Perlembagaan Persekutuan. 
Bagi perihal perundangan agama Islam, terdapat beberapa peruntukan yang boleh dirujuk bagi mengetahui pihak yang mempunyai kuasa terhadapnya. Antaranya, Butiran 1, Senarai Negeri telah memperuntukkan bahawa:

"Kecuali mengenai Wilayah Persekutuan Kuala Lumpur, Labuan dan Putrajaya, hukum Syarak dan undang-undang diri dan keluarga bagi orang yang menganut agama Islam, termasuk hukum Syarak yang berhubungan dengan pewarisan, berwasiat dan tidak berwasiat, pertunangan, perkahwinan, penceraian, mas kahwin, nafkah, pengangkatan, kesahtarafan, penjagaan, alang, pecah milik dan amanah bukan khairat; Wakaf dan takrif serta pengawalseliaan amanah khairat dan agama, pelantikan pemegang amanah pemerbadanan orang berkenaan dengan derma kekal agama dan khairat, institusi, amanah, khairat dan institusi khairat Islam yang beroperasi keseluruhannya di dalam Negeri; adat Melayu; Zakat, Fitrah dan Baitulmal atau hasil agama Islam yang seumpamanya; masjid atau manamana tempat sembahyang awam untuk orang Islam, pewujudan dan penghukuman kesalahan yang dilakukan oleh orang yang menganut agama Islam terhadap perintah agama itu, kecuali berkenaan dengan perkara yang termasuk dalam Senarai Persekutuan; keanggotaan, susunan dan tatacara mahkamah Syariah, yang hendaklah mempunyai bidang kuasa hanya ke atas orang yang menganut agama Islam dan hanya berkenaan dengan mana-mana perkara yang termasuk dalam perenggan ini, tetapi tidak mempunyai bidang kuasa berkenaan dengan kesalahan kecuali setakat yang diberikan oleh undang-undang persekutuan; mengawal pengembangan doktrin dan kepercayaan di kalangan orang yang menganut agama Islam; penentuan perkara mengenai hukum dan doktrin Syarak dan adat Melayu."

Berdasarkan peruntukan di atas, perundangan hal-ehwal Islam di Malaysia dalam aspek-aspek yang telah ditentukan, adalah terletak di bawah bidangkuasa negeri kecuali bagi Wilayah Persekutuan Kuala Lumpur, Labuan dan Putrajaya. Kuasa perundangan bagi ketiga-tiga wilayah tersebut terletak di bawah bidangkuasa kerajaan pusat sepertimana yang telah diperuntukkan dalam Butiran 4(k), Senarai Persekutuan, iaitu:

4. Undang-undang dan tatacara sivil danjenayah dan pentadbiran keadilan, termasuk- 
(k) Penentuan hukum Syarak dan undang-undang diri yang lain bagi maksud undang-undang persekutuan.

Justeru, walaupun agama Islam telah dijadikan sebagai agama bagi Persekutuan, ${ }^{14}$ dan hal ehwal Islam terletak di bawah bidangkuasa kerajaan anegeri, hal ini pada hakikatnya tidaklah mempengaruhi prinsip ketertinggian Perlembagaan. Kedua-dua peruntukan di atas menunjukkan bahawa penggubalan undang-undang Islam yang terpakai kepada orang-orang Islam termasuk mualaf di Malaysia, bukanlah secara mutlak berada di bawah kuasa persekutuan, malah setiap negeri secara berasingan. Sekalipun skop bagi kuasa perundangan Islam yang telah ditentukan itu amat terhad dan sempit, hal ini hendaklah dipatuhi selagimana tiada apa-apa pindaan dibuat terhadap peruntukan berkenaan. Dengan itu, secara tidak langsung, undang-undang bagi mualaf yang boleh digubal di peringkat negeri adalah berkaitan dengan pengurusan hal ehwal diri dan hukum Syarak sahaja seperti pendaftaran Islam, pemberian zakat, bimbingan agama dan sebagainya.

\section{PERUNTUKAN PEMELUKAN ISLAM DALAM UNDANG-UNDANG PENTADBIRAN AGAMA ISLAM NEGERI}

Sepertimana yang dijelaskan sebelum ini, undang-undang Islam di Malaysia digubal secara berasingan oleh setiap negeri. Peruntukan mengenai pemelukan Islam telah diperuntukkan di bawah Enakmen Undang-Undang Pentadbiran Agama Islam negeri-negeri.

Di samping mempunyai nama statut yang berlainan, bentuk dan kandungan peruntukan pemelukan Islam itu sendiri adalah berbeza-beza mengikut apa yang telah diputuskan oleh setiap negeri. Kepelbagaian bentuk dan kandungan peruntukan akan dihuraikan seperti berikut:

a) Nama undang-undang pentadbiran agama Islam negeri;

b) Tajuk peruntukan dan bilangan seksyen; dan

c) Kandungan peruntukan.

\section{a) Nama Undang-Undang Pentadbiran Agama Islam Negeri}

Jadual 1 menunjukkan bahawa setiap negeri mempunyai undang-undang pentadbiran agama Islam bagi dikuatkuasakan di peringkat negeri masingmasing. Dua belas negeri menggunakan istilah 'Pentadbiran'; sama ada Pentadbiran Undang-Undang Islam, Pentadbiran Agama Islam atau

14 Perkara 3, Perlembagaan Persekutuan. 
Pentadbiran Hal Ehwal Agama Islam. Manakala dua lagi negeri menggunakan istilah 'Majlis'; iaitu Majlis Agama Islam dan Adat Istiadat Melayu serta Majlis Islam. Di samping itu, tahun penggubalan undang-undang tersebut juga adalah berbeza-beza mengikut negeri, bermula dari tahun 1991 sehinggalah 2006. Tahun-tahun tersebut adalah berdasarkan kepada pindaan yang dibuat dari semasa ke semasa oleh negeri yang terlibat.

\section{Jadual 1: Statut Undang-Undang Pentadbiran Agama Islam Negeri di Malaysia}

\begin{tabular}{|c|c|c|}
\hline Bil. & Negeri & Nama Statut \\
\hline 1 & $\begin{array}{l}\text { Wilayah } \\
\text { Persekutuan }\end{array}$ & $\begin{array}{l}\text { Akta Pentadbiran Undang-Undang Islam (Wilayah- } \\
\text { Wilayah Persekutuan) } 1993\end{array}$ \\
\hline 2 & Selangor & $\begin{array}{l}\text { Enakmen Pentadbiran Agama Islam (Negeri } \\
\text { Selangor) } 2003\end{array}$ \\
\hline 3 & $\begin{array}{l}\text { Negeri } \\
\text { Sembilan }\end{array}$ & $\begin{array}{l}\text { Enakmen Pentadbiran Agama Islam (Negeri } \\
\text { Sembilan) } 2003\end{array}$ \\
\hline 4 & Melaka & $\begin{array}{l}\text { Enakmen Pentadbiran Agama Islam (Negeri Melaka) } \\
2002\end{array}$ \\
\hline 5 & Johor & $\begin{array}{l}\text { Enakmen Pentadbiran Agama Islam (Negeri Johor) } \\
2003\end{array}$ \\
\hline 6 & Perak & Enakmen Pentadbiran Agama Islam (Perak) 2004 \\
\hline 7 & Pulau Pinang & $\begin{array}{l}\text { Enakmen Pentadbiran Agama Islam (Negeri Pulau } \\
\text { Pinang) } 2004\end{array}$ \\
\hline 8 & Kedah & $\begin{array}{l}\text { Enakmen Pentadbiran Undang-Undang Islam (Kedah } \\
\text { Darul Aman) } 2008\end{array}$ \\
\hline 9 & Perlis & Enakmen Pentadbiran Agama Islam 2006 \\
\hline 10 & Pahang & Enakmen Pentadbiran Undang-Undang Islam 1991 \\
\hline 11 & Terengganu & $\begin{array}{l}\text { Enakmen Pentadbiran Hal Ehwal Agama Islam } \\
\text { (Terengganu) } 2001\end{array}$ \\
\hline 12 & Kelantan & $\begin{array}{l}\text { Enakmen Majlis Agama Islam dan Adat Istiadat } \\
\text { Melayu Kelantan } 1994\end{array}$ \\
\hline 13 & Sabah & Enakmen Majlis Ugama Islam Negeri Sabah 2004 \\
\hline 14 & Sarawak & Ordinan Majlis Islam Sarawak, 2001 \\
\hline
\end{tabular}

Sumber: Portal E-Syariah. ${ }^{15}$

15 Jabatan Kehakiman Syariah Malaysia, 'Rujukan Undang-Undang Syariah,' laman sesawang Portal E-Syariah, www.esyariah.gov.my, 2011. (akses 21 Januari 2018) 


\section{b) Tajuk Peruntukan dan Bilangan Seksyen}

Jadual 2 menunjukkan bahawa semua undang-undang pentadbiran agama Islam negeri mempunyai peruntukan tentang pemelukan agama Islam walaupun terdapat perbezaan pada kedudukan bahagian, tajuk, seksyen dan bilangan peruntukan. Bagi tajuk peruntukan, sepuluh negeri yang menggunapakai istilah 'Memeluk Agama Islam', dua negeri menggunapakai istilah 'Pemelukan Agama Islam', dan masing-masing satu negeri menggunakan istilah 'Masuk Agama Islam' dan 'Masuk Islam'. Selain berada pada kedudukan seksyen yang berlainan, bilangan peruntukan pemelukan Islam itu juga adalah pelbagai mengikut negeri, bermula dari tiga (3) sehinggalah dua belas (12) seksyen dengan majoriti negeri mempunyai sebelas (11) seksyen peruntukan. Perbezaan bilangan peruntukan tersebut adalah dipengaruhi oleh isi kandungan dan penyusunan peruntukan berkenaan yang akan dihuraikan selepas ini.

\section{Jadual 2: Peruntukan Pemelukan Islam dalam Undang-Undang Pentadbiran Agama Islam Negeri di Malaysia}

\begin{tabular}{lll}
\hline \multicolumn{1}{c}{ Negeri } & \multicolumn{1}{c}{ Bahagian dan Tajuk Peruntukan } & \multicolumn{1}{c}{$\begin{array}{c}\text { Seksyen } \\
\text { (Bilangan) }\end{array}$} \\
\hline Wilayah & Bahagian IX - Masuk Islam & $85-95(11)$ \\
$\begin{array}{l}\text { Persekutuan } \\
\text { Selangor }\end{array}$ & Bahagian IX - Memeluk Agama Islam & $107-117(11)$ \\
Negeri & Bahagian IX - Memeluk Agama Islam & $107-117(11)$ \\
Sembilan & Bahagian IX - Memeluk Agama Islam & $95-105(11)$ \\
Melaka & Bahagian IX - Memeluk Agama Islam & $107-117(11)$ \\
Johor & Bahagian IX - Memeluk Agama Islam & $96-106(11)$ \\
Perak & Bahagian IX - Memeluk Agama Islam & $107-117(11)$ \\
Pulau Pinang & Bahagian VII - Memeluk Agama Islam & $70-80(11)$ \\
Kedah & Bahagian IX - Memeluk Agama Islam & $107-117(11)$ \\
Perlis & Bahagian VII - Pemelukan Agama Islam & $100-111(12)$ \\
Pahang & Bahagian VIII - Memeluk Agama Islam & $91-101(11)$ \\
Terengganu & Bahagian VI - Memeluk Agama Islam & $98-102(5)$ \\
Kelantan & Bahagian VI - Masuk Agama Islam & $69-79(11)$ \\
Sabah & Bahagian VIII - Pemelukan Agama Islam & $68-70(3)$ \\
Sarawak & E-Syara
\end{tabular}

Sumber: Portal E-Syariah. ${ }^{16}$

Jabatan Kehakiman Syariah Malaysia, 'Rujukan Undang-Undang Syariah,' laman
sesawang Portal E-Syariah, www.esyariah.gov.my, 2011. (akses 21 Januari 2018) 


\section{c) Kandungan Peruntukan}

Setiap negeri di Malaysia mempunyai peruntukan pemelukan Islam dengan bilangan seksyen yang telah ditentukan oleh penggubal undang-undang negeri masing-masing. Sepertimana yang telah dijelaskan sebelum ini, kebanyakan negeri mempunyai sebelas seksyen peruntukan dan kandungan peruntukan tersebut didapati bersamaan dan seragam antara negeri-negeri berkenaan, melainkan terdapat hanya sedikit perbezaan pada gaya olahan bahasa yang digunakan bagi menyampaikan maksud peruntukan tersebut. Intipati kandungan berkenaan adalah tentang tatacara pemelukan Islam, pendaftaran mualaf dan bagaimana seseorang mualaf itu harus diperlakukan selepas pengislamannya. Sebagai tambahan, terdapat juga negeri yang memperuntukkan tentang status Islam anak-anak mualaf, kawalan pengislaman, halangan untuk keluar Islam dan perlindungan mualaf. Oleh itu, bagi maksud huraian mengenai kandungan peruntukan pemelukan Islam di Malaysia, penjelasan dilakukan mengikut kategori berikut:

i) Tatacara pemelukan Islam;

ii) Pendaftaran mualaf;

iii) Perlakuan oleh atau terhadap mualaf selepas pemelukan Islam;

iv) Status agama anak-anak mualaf; dan

v) Kuasa membuat Kaedah atau Peraturan lanjutan.

\section{i) Tatacara Pemelukan Islam}

Tatacara pemelukan Islam adalah berkisar tentang proses sebelum dan semasa pemelukan Islam tersebut berlangsung. Sebelum menganut agama Islam, seseorang itu hendaklah memenuhi prasyarat yang telah ditentukan bagi menjamin proses pengislaman yang akan dilaksanakan tersebut sah di sisi Syariat Islam. Dengan itu, kesemua negeri kecuali negeri Kelantan, memperuntukkan di dalam salah satu seksyen yang digubal mengenai 'Keupayaan Masuk Islam' atau 'Keupayaan untuk Memeluk Agama Islam'. Sebagai contoh, Seksyen 95 Akta Pentadbiran Undang-Undang Islam (Wilayah-Wilayah Persekutuan) 1993 (selepas ini dirujuk sebagai APUIWP 1993) menyatakan:

Bagi maksud Bahagian ini, seseorang yang tidak beragama Islam boleh masuk Islam jika dia sempurna akal dan-

a) Mencapai umur lapan belas tahun; atau 
b) Jika belum mencapai umur lapan belas tahun, ibu atau bapa atau penjaganya mengizinkan kemasukannya.

Negeri-negeri tidak seragam mengenai keperluan izin sama ada perlu diperolehi daripada salah seorang ibu atau bapa atau dari kedua-dua ibu dan bapa bagi anak yang belum mencapai lapan belas tahun dan ingin memeluk Islam. Keizinan perlu diperolehi daripada salah seorang ibu atau bapa atau penjaga di Wilayah Persekutuan, Negeri Sembilan, Melaka, Kedah dan Sarawak. Bagi negeri Selangor, Pulau Pinang, Perlis dan Terengganu, izin diperlukan daripada kedua-dua ibu dan bapa atau penjaga tetapi, Johor dan Sabah mensyaratkan 'ibubapa atau penjaganya'. Di Perak, disyaratkan supaya keizinan secara bertulis diberikan oleh ibu atau bapa atau penjaga. ${ }^{17}$ Negeri Pahang tidak membuka ruang untuk mana-mana orang yang kurang 18 tahun untuk memeluk Islam. Seksyen 100, Enakmen Pentadbiran Undang-Undang Islam (Pahang) 1991 menegaskan:

"Bagi maksud Bahagian ini, seseorang yang bukan beragama Islam boleh memeluk agama Islam jika ia telah mencapai umur lapan belas tahun dan sempurna akal."

Berdasarkan kepada peruntukan-peruntukan Keupayaan Masuk Islam di atas, setiap orang yang yang telah mencapai umur 18 tahun boleh memeluk agama Islam jika cukup syarat tanpa kezinan dari ibu bapa atau penjaga. Kanakkanak di bawah lapan belas tahun mestilah mendapatkan keizinan ibu atau dan bapa atau penjaganya. Hal ini bertepatan dengan Perkara 12(4), Perlembagaan Persekutuan dan juga keputusan Mahkamah Agong dalam kes In Re Susie Teoh $^{18}$ yang menegaskan bahawa keizinan ibu bapa hendaklah diperolehi sebelum seorang kanak-kanak bawah umur boleh dibenarkan menukar agama.

Setelah syarat dalam peruntukan 'Keupayaan Masuk Islam' di atas dipatuhi, proses seterusnya yang harus dilalui adalah semasa pemelukan Islam tersebut berlangsung. Terdapat kehendak-kehendak yang harus dipenuhi oleh seseorang yang ingin memeluk agama Islam berdasarkan kepada Seksyen 85, Akta Pentadbiran Undang-Undang Islam (Wilayah-Wilayah Persekutuan) 1993, iaitu:

1) Kehendak-kehendak yang berikut hendaklah dipatuhi bagi kemasukan sah seseorang itu ke dalam agama Islam:

17 Seksyen 106, Enakmen Pentadbiran Agama Islam (Perak) 2004.

18 Teoh Eng Huat lawan Kadhi of Pasir Mas Kelantan \& Majlis Agama Islam dan Adat Istiadat Melayu, Kelantan [1986] 2 MLJ 228. 
a) orang itu mestilah mengucapkan dua kalimah Syahadah dalam bahasa Arab secara semunasabahnya jelas;

b) pada masa mengucap dua kalimah itu, orang itu mestilah sedar bahawa ia bermakna "Aku naik saksi bahawa tiada tuhan melainkan Allah dan aku naik saksi bahawa Nabi Muhammad S.A.W ialah Pesuruh Allah"; dan

c) pengucapan itu mestilah dibuat dengan kerelaan hati orang itu sendiri.

2) Seseorang yang tidak dapat bercakap boleh, bagi maksud memenuhi kehendak perenggan (a) subseksyen (1), mengucapkan dua kalimah Syahadah dengan cara isyarat yang menunjukkan makna yang dinyatakan dalam perenggan (b) subseksyen itu.

Kehendak-kehendak di atas adalah seragam di negeri-negeri, kecuali Kelantan dan Sarawak. Di Sarawak, tiada pernyataan khusus tentang kehendakkehendak yang harus dipatuhi semasa pengislaman dan hanya dinyatakan dalam Seksyen 68 (1), Ordinan Majlis Islam Sarawak, 2001 seperti berikut:

Seseorang yang bukan Islam dan ingin memeluk agama Islam hendaklah mematuhi segala kehendak yang perlu mengikut Undang-Undang Islam bagi pemelukan sah agama Islam.

Manakala bagi Kelantan pula, peruntukan yang berkaitan dengan proses pengislaman - tanpa menyebut syarat umur - adalah menurut Seksyen 100, Enakmen Majlis Agama Islam dan Adat Istiadat Melayu Kelantan 1994:

1) Seseorang yang hendak memeluk Agama Islam hendaklah melafaz dua kalimah syahadah di hadapan mana-mana orang Islam dan selepas itu hendaklah hadir menemui Qadhi atau mana-mana orang yang dilantik oleh Majlis.

2) Qadhi atau mana-mana orang yang dilantik oleh Majlis hendaklah memeriksa perihal orang itu dan setelah berpuas hati, hendaklah membuat perakuan kepada Yang Dipertua untuk didaftarkan.

Kesan daripada lafaz syahadah dan pengislaman yang sah, maka seseorang itu akan menjadi seorang 'muallaf'. Hal ini berdasarkan kepada peruntukanperuntukan seksyen 'Saat Masuk Islam' atau 'Kesan Memeluk Agama Islam' di dalam Undang-Undang Pentadbiran Agama Islam Negeri, kecuali di negeri 
Kelantan tiada pernyataan sedemikian. Contohnya, peruntukan Seksyen 86, APUIWP 1993 telah menyatakan bahawa:

Seseorang itu masuk Islam dan menjadi seorang Islam sebaikbaik sahaja dia habis mengucapkan dua kalimah Syahadah dengan syarat bahawa kehendak-kehendak seksyen 85 adalah dipenuhi, dan orang itu hendaklah selepas itu disebut sebagai seorang muallaf.

\section{ii) Pendaftaran Mualaf ${ }^{19}$}

Bagi tujuan rekod dan identiti seseorang mualaf, setiap mualaf yang telah sempurna proses masuk Islam hendaklah kemudiannya mendaftarkan pengislaman mereka di Majlis atau Jabatan Agama Islam Negeri. Negerinegeri di Malaysia telah menetapkan supaya melantik seorang 'Pendaftar Muallaf' bagi mengelolakan suatu Daftar Mualaf di negeri berkenaan (Kelantan menggunakan istilah Qadhi di bawah seksyen 100 Enakmen MAIK 1994. Tiada jawatan Pendaftar Mualaf di Kelantan). Peruntukan Seksyen 88, Akta Pentadbiran Undang-Undang Islam (Wilayah-Wilayah Persekutuan) 1993 berkaitan perkara tersebut ada menyatakan bahawa:

"Seseorang Pendaftar Muallaf hendaklah dilantik oleh Majlis untuk menyelenggarakan suatu Daftar Muallaf dalam bentuk yang ditetapkan untuk pendaftaran muallaf. "

Di samping itu, terdapat juga negeri yang memperuntukkan individu yang khusus sebagai Pendaftar Muallaf, seperti di Sarawak ${ }^{20}$ yang menyatakan bahawa 'Pengarah Jabatan Agama Islam Negeri sebagai Pendaftar Pemeluk Agama Islam' di negeri berkenaan. Manakala di Selangor ${ }^{21}$ pula, 'Ketua Pendaftar Muallaf dan Pendaftar Muallaf' telah dilantik bagi tujuan tersebut.

Seterusnya, proses pendaftaran mualaf di setiap negeri adalah berdasarkan kepada peruntukan 'Pendaftaran Muallaf' atau 'Pendaftaran Pemelukan Agama Islam', kecuali di Kelantan dan Sarawak. Sebagai contoh peruntukan Seksyen 89, Akta Pentadbiran Undang-Undang Islam (Wilayah-Wilayah Persekutuan) 1993 adalah seperti berikut:

19 Ejaan 'mualaf' dan 'muallaf' digunakan secara bertukar ganti. Ejaan muallaf digunakan sebagaimana yang digunakan di dalam sesetengah enakmen, manakala secara umum, ejaan mualaf digunakan.

20 Seksyen 70 (1), Ordinan Majlis Islam Sarawak, 2001.

21 Seksyen 110, Enakmen Pentadbiran Agama Islam (Negeri Selangor) 2003 (Pindaan) 2011. 
1) Seseorang yang telah masuk Islam boleh memohon kepada Pendaftar dalam borang yang ditetapkan untuk pendaftaran sebagai seorang muallaf.

2) Jika Pendaftar berpuas hati bahawa kehendak-kehendak seksyen 85 telah dipenuhi berkenaan dengan orang itu, Pendaftar boleh mendaftarkan kemasukan Islam orang itu dengan mencatatkan dalam Daftar Muallaf nama orang itu dan butirbutir lain sebagaimana yang dikehendaki dalam Daftar.

3) Pendaftar hendaklah juga menentukan tarikh masuk Islam dan mencatatkan tarikh itu dalam Daftar Muallaf.

4) Untuk memuaskan hatinya akan hal dan tarikh masuk Islam, dan butir-butir lain yang hendak dicatatkan dalam Daftar Muallaf, Pendaftar boleh membuat siasatan-siasatan dan memanggil apa-apa keterangan sebagaimana yang dia fikirkan perlu, tetapi subseksyen ini tidak boleh ditafsirkan sebagai menghalang Pendaftar daripada hanya bergantung kepada kata pemohon bagi kemasukan Islam itu setakat yang berkenaan dengan hal dan tarikh masuk Islam itu.

5) Jika Pendaftar tidak berpuas hati bahawa kehendakkehendak seksyen 85 telah dipenuhi berkenaan dengan pemohon bagi kemasukan Islam, dia boleh membenarkan pemohon itu mengucap, di hadapannya atau mana-mana pegawainya, dua kalimah Syahadah mengikut kehendak-kehendak seksyen itu.

Walaupun di Kelantan tiada peruntukan khusus tentang penentuan atau pelantikan seorang Pendaftar Muallaf, namun tugas pendaftaran dijalankan di bawah Bahagian Dakwah MAIK Seksyen namun Seksyen 98 dan 99, Enakmen Majlis Agama Islam dan Adat Istiadat Melayu Kelantan 1994 telah memperuntukkan tugas pendaftaran ini:

\section{Seksyen 98. Daftar orang yang memeluk Agama Islam}

Majlis hendaklah menyimpan suatu daftar nama semua orang yang memeluk Agama Islam dalam Negeri ini bersama-sama dengan butir-butir kenyataan berkenaan orang-orang itu seperti yang ditetapkan dalam kaedah-kaedah yang dibuat di bawah Enakmen ini. 


\section{Seksyen 99. Kawalan.}

Seseorang itu tidak boleh didaftarkan sebagai orang yang memeluk Agama Islam, melainkan menurut peruntukanperuntukan di dalam Enakmen ini, atau kaedah-kaedah yang dibuat di bawahnya.

Setelah selesai proses pendaftaran mualaf seperti peruntukan-peruntukan di atas, sebagai identiti rasmi seseorang mualaf, setiap mualaf yang telah didaftarkan akan diberikan sama ada Perakuan Masuk Islam iaitu bagi Wilayah Persekutuan dan Sabah, Sijil Pemelukan Agama Islam bagi negeri Pahang, Kad Perakuan memeluk agama Islam bagi negeri Sarawak ataupun selain negerinegeri yang telah disebutkan akan diberikan Perakuan Memeluk Agama Islam. Meskipun begitu, di Kelantan tiada pernyataan tentang perkara ini. Perakuan, Kad ataupun Sijil tersebut akan menjadi bukti muktamad seseorang mualaf itu sepertimana yang dinyatakan dalam peruntukan Seksyen 90, Akta Pentadbiran Undang-Undang Islam (Wilayah-Wilayah Persekutuan) 1993 di bawah:

1) Pendaftar hendaklah memberikan kepada tiap-tiap orang yang kemasukan Islamnya telah didaftarkan suatu Perakuan Masuk Islam dalam borang yang ditetapkan.

2) Perakuan Masuk Islam hendaklah menjadi bukti muktamad akan hal-hal yang dinyatakan di dalamnya.

Kewujudan peruntukan khusus bagi pendaftaran seseorang mualaf seperti di atas adalah sangat penting memandangkan ia akan menjadi bukti muktamad dan rekod rasmi sekiranya terdapat sebarang pertikaian mengenainya, sama ada pertikaian yang berlaku saat hidup mahupun selepas kematian manamana mualaf. Sebagai contoh, kes penentuan status agama si mati Moorthy a/l Maniam $^{22}$ semasa perebutan mayat beliau untuk dikebumikan sama ada mengikut agama Islam ataupun Hindu. Si mati yang telah merahsiakan pemelukan Islamnya daripada pengetahuan keluarga, akhirnya telah diputuskan oleh Mahkamah Syariah sebagai seorang Islam dan hendaklah dikebumikan mengikut cara Islam. Mahkamah Syariah membuat keputusan berdasarkan kepada surat dan dokumen-dokumen pendaftaran Islam si mati yang dikemukakan oleh pihak Jabatan Agama Islam Wilayah Persekutuan.

Di samping keperluan pendaftaran mualaf, terdapat juga peruntukan lain dalam undang-undang yang menjelaskan 'Kesalahan Memberi Maklumat Palsu' sepertimana Seksyen 93, Akta Pentadbiran Undang-Undang Islam (Wilayah-Wilayah Persekutuan) APUIWP 1993:

$\overline{22 \quad[2006] \mathrm{JH} \text { XII, }} 221$. 
"Mana-mana orang yang, dalam suatu permohonan untuk pendaftaran di bawah seksyen 89, atau sebagai jawapan kepada apa-apa permintaan untukmaklumat atau keterangan yang dibuat oleh Pendaftar di bawah seksyen itu, dengan sengaja memberi kepada Pendaftar apa-apa maklumat atau keterangan palsu atau yang mengelirukan adalah melakukan suatu kesalahan dan apabila disabitkan boleh didenda tidak melebihi satu ribu ringgit atau dipenjara selama tempoh tidak melebihi enam bulan atau kedua-duanya."

Hukuman denda dan penjara bagi kesalahan memalsukan maklumat keterangan adalah bersamaan bagi kebanyakan negeri di Malaysia, kecuali di negeri Terengganu ${ }^{23}$ yang meletakkan hukuman 'boleh didenda tidak melebihi satu ribu ringgit atau dipenjarakan selama tempoh tidak melebihi enam belas bulan atau kedua-duanya'. Tiada peruntukan sedemikian di negeri Kelantan dan Sarawak.

Selain itu, bagi menentukan sama ada orang yang tidak didaftarkan ialah seorang mualaf ataupun tidak hendaklah merujuk kepada kehendak-kehendak bagi masuk Islam (lafaz Syahadah) yang telah dipenuhi dan dipatuhi, sebagaimana yang diperuntukkan oleh Seksyen 92, Akta Pentadbiran UndangUndang Islam (Wilayah-Wilayah Persekutuan) APUIWP 1993:

Jika apa-apa soalan timbul dalam Wilayah-Wilayah Persekutuan sama ada seseorang itu adalah seorang muallaf, dan orang itu tidak didaftarkan dalam Daftar Muallaf atau di bawah manamana undang-undang mana-mana Negeri sebagai seorang muallaf, soalan itu hendaklah diputuskan berdasarkan kepada merit kes itu megikut seksyen 85.

Peruntukan seperti di atas adalah bersamaan di semua negeri kecuali negeri Pahang ${ }^{24}$ yang menyatakan bahawa persoalan itu hendaklah 'diputuskan oleh Mahkamah Tinggi Syariah menurut Hukum Syarak'.

\section{iii) Perlakuan Oleh atau Terhadap Mualaf Selepas Pemelukan Islam}

Setiap individu yang beragama mempunyai obligasi masing-masing yang telah ditentukan oleh setiap agama itu sendiri. Begitu juga dengan mualaf sebagai penganut agama Islam, mereka mempunyai kewajipan dan tanggungjawab

23 Seksyen 99, Enakmen Pentadbiran Hal Ehwal Agama Islam (Terengganu).

24 Seksyen 109, Enakmen Pentadbiran Undang-Undang Islam 1991. 
yang harus ditunaikan bagi menyempurnakan agama yang dianuti, walaupun masih lagi baru dan berjinak-jinak untuk mengenali Islam. Bagi menjelaskan perkara ini, terdapat peruntukan undang-undang di setiap negeri di Malaysia, kecuali di Kelantan dan Sarawak, untuk menyatakan bahawa setiap mualaf itu adalah terikat kepada tugas, kewajipan dan obligasi sebagai penganut agama Islam. Antara peruntukan berkenaan adalah Seksyen 87, APUIWP 1993 seperti berikut:

"Dari saat kemasukannya, seseorang muallaf menjadi tertakluk kepada tugas-tugas dan kewajipan-kewajipan yang sama seperti mana-mana orang Islam yang lain."

Manakala bagi negeri Pahang pula, di samping mengetengahkan mengenai kewajipan yang harus dilakukan oleh mualaf, peruntukan Seksyen 104, Enakmen Pentadbiran Undang-Undang Islam 1991 di bawah juga menunjukkan bahawa mualaf juga mempunyai hak sepertimana orang-orang Islam yang lain, iaitu:

"Dari saat dia memeluk agama Islam, seseorang muallaf, termasuk muallaf kanak-kanak, mempunyai hak dan kewajipan yang sama seperti orang Islam yang lain."

Bagi menghuraikan lagi peruntukan-peruntukan lain yang wujud mengenai perlakuan atau layanan terhadap seseorang mualaf, terdapat peruntukan mengenai 'Pengiktirafan Mualaf sebagai Orang Islam'. Peruntukan ini mengiktiraf setiap mualaf supaya pada setiap masa dilayani sebagai orang Islam sama ada dalam perkara mal mahupun perkara jenayah. Sebagai contoh peruntukan seumpama itu dalam Seksyen 91, APUIWP 1993 adalah:

1) Seseorang yang telah masuk Islam dan telah didaftarkan dalam Daftar Muallaf hendaklah, bagi maksud mana-mana undang-undang Persekutuan atau Negeri, dan untuk semua masa, diperlakukan sebagai seorang Islam.

2) Seseorang yang kemasukan Islamnya dan telah didaftarkan di bawah mana-mana undang-undang mana-mana Negeri hendaklah, bagi semua maksud di Wilayah-Wilayah Persekutuan dan bagi maksud-maksud menguatkuasakan di Wilayah-Wilayah Persekutuan peruntukan-peruntukan mana-mana undangundang, diperlakukan sebagai seorang Islam.

Berdasarkan peruntukan di atas, setiap perihal dan perlakuan mualaf yang bersangkutan dengan skop undang-undang Islam di Malaysia hendaklah dibicarakan serta diputuskan di Mahkamah Syariah dan bukan lagi di 
Mahkamah Sivil memandangkan mereka hendaklah dilayani sebagai seorang Islam. Dalam kes Re Emily binti Abdullah@ Yeo Leng Neo (1996), ${ }^{25}$ diputuskan bahawa harta pusaka si mati mualaf hendaklah dibahagikan kepada waris yang beragama Islam sahaja, iaitu suaminya dan baki harta tersebut adalah dikembalikan kepada Baitulmal memandangkan si mati tidak lagi mempunyai waris beragama Islam yang lain. Hal ini diputuskan mengikut hukum Syarak di Mahkamah Syariah. Begitu juga dalam kes Jabatan Hal Ehwal Agama Islam Negeri Sembilan lawan Faridah Chin dan Seorang Lagi (1996) ${ }^{26}$, yang mana wasiat si mati yang telah memeluk agama Islam supaya mayatnya dibakar telah diputuskan tidak sah oleh Mahkamah Syariah kerana bercanggah dengan hukum Syarak.

Sekalipun di Sarawak dan Kelantan tiada peruntukan yang serupa dengan peruntukan-peruntukan di atas, namun di Kelantan telah diadakan dua peruntukan lain bagi menyatakan tentang perlakuan oleh atau terhadap mualaf selepas pengislaman mereka. Peruntukan yang pertama adalah mengenai 'Kuasa Perlindungan' sepertimana Seksyen 101, Enakmen Majlis Agama Islam dan Adat Istiadat Melayu Kelantan 1994 yang berikut:

1) Dengan tidak menghiraukan apa-apa hak yang dipunyai oleh mana-mana orang lain atau badan-badan, Majlis bolehlah memberi kepada mana-mana orang yang baru memeluk Agama Islam, bantuan, perlindungan, pelajaran agama, keselamatan, kebajikan dan lain-lain perkara yang berbangkit dalam tempoh tertentu.

2) Majlis boleh, pada bila-bila masa, menamatkan tempoh bantuan ke atas seseorang yang baru memeluk Agama Islam.

Peruntukan di atas menunjukkan bahawa, kebajikan mualaf di Kelantan dalam bentuk-bentuk yang dinyatakan adalah menjadi hak yang boleh diperolehi daripada pihak Majlis Agama Islam Negeri dalam tempoh masa tertentu. Manakala peruntukan kedua yang akan dijelaskan selepas ini pula adalah mengenai 'Pengesahan Seseorang Islam' yang berlegar tentang isu kewajipan seseorang mualaf dan sekiranya mereka cuba keluar agama. Peruntukan Seksyen 102, Enakmen Majlis Agama Islam dan Adat Istiadat Melayu Kelantan 1994 menyebutkan bahawa:

25 Jasni Sulong, 'Hak Saudara Baru terhadap Harta Pusaka: Analisis Undang-Undang Semasa,' Jurnal Islam dan Masyarakat Kontemporari, bil. 8 (2014): 29.

26 [1996] JH X/II, 195. 
1) Tiada seorangpun yang telah diakui beragama Islam boleh mengaku bahawa dia bukan Islam melainkan setelah Mahkamah memberi pengesahan sedemikian.

2) Sebelum Mahkamah membuat pengesahannya, seseorang itu hendaklah dianggap beragama Islam dan segala perkara yang berkaitan dengan Agama Islam adalah terkena ke atasnya.

3) Jika seseorang Islam dengan sengaja cuba sama ada dengan perkataan atau perbuatan hendak keluar dari Agama Islam, Mahkamah bolehlah, jika berpuashati, memerintahkan orang itu supaya ditahan di Pusat Bimbingan Islam untuk tempoh tidak melebihi 36 bulan bagi tujuan pendidikan dan orang itu hendaklah diminta bertaubat mengikut Hukum Syarak.

\section{iv) Status Agama Anak-Anak Mualaf}

Berkenaan status anak-anak mualaf, didapati hanya Pahang sahaja yang memperuntukkan secara khusus perincian mengenainya. Terdapat empat peruntukan yang boleh dirujuk bagi menjelaskan perkara ini. Peruntukan yang pertama, Seksyen 103, Enakmen Pentadbiran Undang-Undang Islam 1991 menyatakan bahawa:

"Jika pada saat dia memeluk agama Islam, seseorang muallaf sama ada lelaki atau perempuan, ada mempunyai anak yang belum mencapai umur lapan belas tahun, dan anak itu telah diperintahkan oleh mahkamah, selain daripada Mahkamah Syariah, supaya diletakkan di bawah penjagaan muallafitu, dan muallaf itu menetapkan supaya anak itu memeluk agama Islam, maka anak tersebut adalah memeluk agama Islam pada masa penjagaan diberi."

Peruntukan seperti di atas mampu menyelesaikan pertikaian yang wujud berkenaan dengan status agama anak-anak mualaf. Tanpa peruntukan sebegini, banyak kes terpaksa diselesaikan oleh mahkamah selain Mahkamah Syariah. Antaranya pertikaian yang berlaku oleh pasangan dari Negeri Sembilan, kes Subashini a/p Rajasingam lawan Saravanan a/l Thangathoray and other appeals ${ }^{27}$, yang mana Mahkamah Persekutuan menyatakan bahawa pengislaman anak di bawah umur 18 tahun oleh si bapa adalah dibolehkan, memandangkan hanya keizinan salah seorang ibu atau bapa sahaja yang

$27 \quad[2008] 2$ MLJ 147. 
diperlukan. Perkara ini berbeza dengan kes yang berlaku di Perak iaitu Indira Ghandi a/p Mutho lawan Pengarah Jabatan Agama Islam Perak \& Ors ${ }^{28}$, yang mana penukaran agama anak bawah umur 18 tahun oleh salah seorang ibu atau bapa adalah tidak dibenarkan oleh mahkamah, sebaliknya perlu mendapat izin kedua ibu dan bapa si anak. Walaupun terdapat perbezaan penghakiman yang dibuat menurut kes-kes di atas, namun apa yang boleh diperhatikan di sini adalah, pertikaian-pertikaian seumpama itu biasanya berlaku sekiranya hanya salah seorang ibu atau bapa si anak tersebut sahaja yang telah masuk Islam. Sebaliknya, jika kedua-dua pasangan suami dan isteri masuk Islam, pertikaian tentang penentuan agama si anak tidak berlaku kerana si anak akan mengikut agama baru kedua ibu dan bapanya sahaja. ${ }^{29}$

Proses seterusnya yang telah ditetapkan di Pahang, selepas anak-anak mualaf tersebut memeluk agama Islam berdasarkan kepada peruntukan di atas, mereka hendaklah didaftarkan sebagaimana orang tua mereka. Terdapat peruntukan mengenainya yang dinyatakan di bawah Seksyen 106 (3)(4)(5), Enakmen Pentadbiran Undang-Undang Islam 1991 seperti berikut:

3) Jika Pendaftar Muallafberpuas hati bahawa seseorang muallaf telah diberi penjagaan di bawah seksyen 103 terhadap anak yang pada saat pemelukan muallaf itu ke agama Islam adalah berumur kurang daripada lapan belas tahun, Pendaftar Muallaf hendaklah atas permohonan muallaf tersebut mendaftarkan juga pemelukan ke agama Islam anak itu dalam Daftar Muallaf.

4) Pendaftar muallaf hendaklah juga menentukan tarikh seseorang itu memeluk agama Islam dan mencatatkan tarikh itu di dalam Daftar Muallaf.

5) Bagi maksud memuaskan hatinya akan hal dan tarikh pemelukan ke agama Islam, tentang adanya anak pemohon, dan umur anak itu dan butir-butir lain, Pendaftar Muallaf boleh membuat siasatan dan boleh mendapatkan keterangan sebagaimana yang difikirkannya mustahak, tetapi subseksyen ini

28 [2013] 5 MLJ 552. Lihat yang terkini

29 Pindaan terbaru Rang Undang-Undang 164 yang menyatakan bahawa agama anak-anak adalah kekal mengikut agama asal mereka sehinggalah mencapai umur 18 tahun telah menimbulkan konflik perundangan dan hukum Syarak itu sendiri. Rujuk Berita Astro Awani, 'Kekeliruan Libatkan Mualaf: Mufti Perak Gesa Kerajaan Tarik Balik Keputusan Pinda Akta 164,' laman sesawang Astro Awani, http://www.astroawani.com/berita-malaysia/kekeliruan-libatkan-mualaf-muftiperak-gesa-kerajaan-tarik-balik-keputusan-pinda-akta-164-137833, 3 April 2017. 
tidak boleh dianggap sebagai menghalang Pendaftar Muallaf daripada bergantung hanya kepada kata-kata pemohon setakat yang mengenai hal pemelukannya dan tarikhnya.

Setelah anak mualaf tersebut didaftarkan pengislaman mereka, maka mereka akan diberikan Sijil Pemelukan Agama Islam sepertimana yang dinyatakan dalam peruntukan Seksyen 107 (2)(3), Enakmen Pentadbiran Undang-Undang Islam 1991 di bawah:

2) Sijil Pemelukan Agama Islam untuk kanak-kanakyang memeluk agama Islam hendaklah diberikan kepada ibu atau bapanya yang telah memeluk agama Islam atau jika kedua-dua ibu bapanya telah memeluk agama Islam, sijil tersebut hendaklah diserahkan kepada bapanya.

3) Sijil Pemelukan Agama Islam hendaklah menjadi bukti muktamad akan hal yang terkandung di dalamnya.

Bagi menyatakan tentang hak dan kewajipan anak-anak mualaf yang telahpun memeluk agama Islam di Pahang, peruntukan yang keempat, Seksyen 104, Enakmen Pentadbiran Undang-Undang Islam 1991 ini menyebut bahawa:

"Dari saat dia memeluk agama Islam, seseorang muallaf, termasuk muallaf kanak-kanak, mempunyai hak dan kewajipan yang sama seperti orang Islam yang lain."

Ternyata bahawa, status agama bagi anak-anak mualaf di negeri Pahang adalah ditentukan oleh ibu atau bapa mereka, sekiranya pada masa pengislaman ibu atau bapa berkenaan, mereka telah mendapat hak jagaan anak itu yang diperoleh daripada Mahkamah Sivil; iaitu selepas berlakunya penceraian pasangan tersebut. Dengan pengislaman anak-anak mualaf tersebut, maka mereka adalah terikat untuk menjalani kehidupan sebagai orang Islam dalam seluruh perkara sepertimana kanak-kanak Islam yang lain. Meskipun begitu, isu status agama anak-anak mualaf ini tidak hanya terhenti di situ sahaja. Polemik lain yang sering timbul adalah tentang status agama anak yang diputuskan oleh mahkamah untuk berada di bawah jagaan pihak bukan Islam kerana menjaga kebajikan si anak tersebut. Bahkan, terdapat juga isu lain apabila wujudnya anak-anak mualaf yang membuat permohonan untuk menukar agama kepada agama lain setelah berusia lapan belas tahun, atas alasan masuk Islam semasa kanak-kanak hanya disebabkan oleh ibu bapa yang masuk Islam. ${ }^{30}$

$30 \quad$ Pg Ismail Pg Musa \& Siti Zubaidah Ismail, Permohonan Keluar Islam: Kajian Kes di Mahkamah Tinggi Syariah Negeri Sabah: 70; Lihat juga MalaysiaKini, 'Revathi: That's My Name, Forever,' laman sesawang MalaysiaKini, http://www. malaysiakini.com/news/69818, 11 Julai 2007. 


\section{v) Kuasa Membuat Kaedah atau Peraturan Lanjutan}

Seksyen 94, APUIWP 1993 telah memperuntukkan bahawa:

\section{Majlis boleh membuat kaedah-kaedah bagi melaksanakan peruntukan-peruntukan Bahagian ini.}

Kaedah-kaedah lanjutan tersebut adalah bagi memperincikan lagi pelaksanaan seluruh peruntukan pemelukan Islam dalam Akta tersebut. Bukan sahaja di Wilayah Persekutuan, malah di Pahang dan Sabah juga telah memberikan kuasa kepada pihak Majlis Agama Islam Negeri untuk mengadakan kaedah seumpama itu. Manakala di negeri-negeri yang lain selain Kelantan dan Sarawak, istilah 'Peraturan-Peraturan' adalah digunakan bagi tujuan dan maksud yang sama. ${ }^{31}$

Sekalipun di Kelantan tidak mempunyai peruntukan yang secara langsung memberikan kuasa untuk mengadakan Kaedah lanjutan tersebut, namun terdapat beberapa peruntukan yang telah secara tidak langsung menunjukkan bahawa Kaedah-Kaedah lanjutan seumpama itu seharusnya diadakan bagi melaksanakan peruntukan pemelukan Islam di dalam Enakmen Majlis Agama Islam dan Adat Istiadat Melayu Kelantan 1994. Antaranya, peruntukan Seksyen 99, Enakmen Majlis Agama Islam dan Adat Istiadat Melayu Kelantan 1994:

"Seseorang itu tidak boleh didaftarkan sebagai orang yang memeluk Agama Islam, melainkan menurut peruntukanperuntukan di dalam Enakmen ini, atau kaedah-kaedah yang dibuat di bawahnya."

\section{ANALISIS}

Berdasarkan kepada penjelasan dan huraian yang telah diolah dalam bahagian sebelum ini, ternyata bahawa adalah satu usaha yang baik apabila kesemua negeri telahpun mempunyai peruntukan pemelukan Islam dalam Akta atau Enakmen atau Ordinan Pentadbiran Agama Islam Negeri masing-masing. Setelah dibentangkan kesemua peruntukan tersebut, suatu analisis secara tekstual dan normatif-juridikal dibuat berdasarkan kepada empat elemen utama. Selain itu, analisis yang akan dijelaskan pada bahagian ini juga bukanlah hanya bertumpu kepada perbezaan yang wujud antara peruntukan

31 Kaedah mahupun Peraturan tersebut dikenali sebagai perundangan subsidiari atau perwakilan; iaitu undang-undang kecil yang dibuat oleh pihak berkuasa pentadbiran seperti Majlis Agama Islam Negeri di bawah kuasa-kuasa yang diberikan oleh statut induk seperti Akta atau Enakmen Pentadbiran Agama Islam Negeri. 
di negeri-negeri sahaja. Namun, fokus utama perbahasan dalam setiap elemen adalah berdasarkan kepada maksud dan kandungan peruntukan.

\section{a) Tatacara Pengislaman dan Pendaftaran}

Tatacara pengislaman dan pendaftaran yang digariskan dalam peruntukan sedia ada adalah ringkas dan dapat difahami dengan mudah. Tatacara pengislaman adalah bermula daripada syarat keupayaan sebelum pemelukan Islam, diikuti dengan proses pengislaman (lafaz syahadah secara sukarela) dan kesan daripada pemelukan Islam yang sah kepada individu berkenaan. Seterusnya, tatacara pendaftaran pula adalah bermula dengan pernyataan mengenai Pendaftar dan Daftar Mualaf, kemudian barulah diikuti dengan proses pendaftaran dan pemberian Perakuan seseorang mualaf, kesalahan dalam memberikan keterangan palsu serta akhir sekali cara menentukan sama ada orang yang tidak berdaftar itu mualaf ataupun tidak. Peruntukanperuntukan tersebut menunjukkan bahawa pengislaman seseorang mualaf itu bukanlah semestinya di hadapan pihak berkuasa agama negeri. Sebaliknya, bagi tujuan daftar dan rekod serta perakuan identiti seseorang individu mualaf itu, pihak Majlis atau Jabatan Agama Islam Negeri adalah bertanggungjawab penuh ke atasnya. Sekalipun jika dilihat terdapat dua pihak yang berbeza dalam menyempurnakan pengislaman dan pendaftaran tersebut, hal ini tidaklah menjadi permasalahan utama kerana persyaratan dalam mendaftarkan pengislaman tersebut sudah mencukupi untuk mengenalpasti sama ada lafaz syahadah yang diungkapkan tersebut adalah sah mahupun tidak. Perkara ini juga dapat memudahkan individu mualaf itu sendiri, supaya pemelukan Islam yang ingin dilakukan tidak bertangguh akibat terpaksa menunggu pada hari bekerja sahaja.

Meskipun hampir semua negeri telahpun mempunyai peruntukan tatacara dan prosedur pengislaman dan pendaftaran yang kemas, namun Kelantan dan Sarawak masih menggunapakai peruntukan umum mengenai perkara ini. Lebih elok jika ianya diperincikan satu-persatu agar undang-undang dan amalan adalah selari dan bersistematik. Peruntukan sedia ada di semua negeri itu juga masih belum memadai secara praktikalnya. Hal ini kerana, masih wujud beberapa persoalan yang perlu diperjelas lagi seperti, siapakah pihak yang kompeten untuk mengislamkan seseorang mualaf dan adakah saksi menjadi syarat utama bagi kesahan pengislaman tersebut? Selain itu, apakah dokumen yang perlu disediakan bagi menyempurnakan kedua-dua proses pengislaman dan pendaftaran tersebut? Penjelasan terhadap persoalan yang timbul tersebut 
adalah perlu supaya tidak wujud sebarang keraguan yang boleh dicabar semasa menentukan kesahan pemelukan Islam seseorang mualaf itu.

\section{b) Obligasi dan Hak Mualaf}

Semua negeri di Malaysia, kecuali Sarawak telahpun mengadakan peruntukan secara umum mengenai kewajipan dan obligasi yang harus dipikul oleh setiap mualaf. Setiap individu mualaf itu mestilah berperilaku mengikut kehendak Syarak sepertimana orang-orang Islam yang lain. Manakala dari aspek hak yang berhak diterima oleh mualaf pula, peruntukan sedia ada menunjukkan bahawa mereka akan dilayani sebagai seorang Islam sama ada dalam perkara mal mahupun jenayah. Dengan itu, bagi perkara yang bersangkutan dengan aspek undang-undang Islam di Malaysia, kes bagi mualaf akan dibicara dan diputuskan di Mahkamah Syariah kecuali yang berkaitan dengan nikah cerai dan tuntutan lain bersama pasangan bukan Islam.

Walaupun begitu, peruntukan bagi pemberian hak kepada mualaf di semua negeri terutamanya dalam soal perlindungan, kebajikan, pendidikan dan sebagainya tidak dinyatakan secara khusus melainkan di negeri Kelantan sahaja. Umpamanya mengenai kaedah agihan zakat kepada mereka atau pemberian wang saguhati. Terdapat pelbagai kaedah digunakan seperti dibayar setiap kali hadir kelas pengajian, dibayar sewaktu memeluk Islam dan sebagainya. Dalam soal ini, sekalipun Kelantan mempunyai seksyen khusus mengenainya, namun peruntukan tersebut masih belum mencukupi bagi memperjelas kaedah pengurusan bantuan kewangan, kebajikan dan pendidikan mualaf berkenaan.

\section{c) Status Agama Anak-Anak Mualaf}

Berdasarkan kepada huraian sebelum ini, hanya negeri Pahang sahaja yang telah mengadakan peruntukan berkenaan dengan status agama anak mualaf. Bermula daripada cara untuk mengislamkan anak mualaf; iaitu dengan persetujuan pihak ibu atau bapa mualaf yang telah mendapat hak jagaan anak tersebut, diikuti dengan pendaftaran dan perolehan Sijil Pemelukan Agama Islam serta hak dan kewajipan anak mualaf tersebut. Adakah negeri-negeri akan menambah peruntukan sebegini ke dalam enakmen masing-masing atau adakah keputusan kes Indira Gandhi akan mempengaruhi keputusan membuat penentuan status anak. Selain itu, bagi menangani isu anak-anak mualaf yang ingin meninggalkan agama Islam apabila meningkat dewasa dengan alasan memeluk Islam semasa kecil hanya kerana mengikut kehendak orang tua, 
peruntukan mengenai hak dan kewajipan anak mualafjuga haruslah diperkemas dan mempunyai perincian lanjut untuk memenuhi keperluan spiritual dan material anak-anak mualaf tersebut. Hal ini supaya dapat meneguhkan akidah dan pengamalan agama mereka sejak kecil lagi.

\section{d) Undang-undang Lanjutan bagi Kesinambungan Peruntukan}

Semua negeri di Malaysia kecuali Sarawak mempunyai peruntukkan supaya diadakan Kaedah atau Peraturan bagi menguatkuasakan peruntukanperuntukan pemelukan Islam dalam undang-undang pentadbiran agama Islam negeri masing-masing. Kaedah atau Peraturan lanjutan tersebut adalah amat perlu sebagai pelengkap kepada peruntukan yang bersifat umum dalam statut induk di samping bagi mengisi kelompangan dalam perkara-perkara yang dibincangkan di atas seperti mengenai kaedah pengislaman, pendaftaran mahupun tugas dan hak bagi mualaf supaya kesemua perkara tersebut dapat diperincikan dengan lebih mendalam lagi. Tambahan pula, sebagai undangundang subsidiari, Kaedah atau Peraturan tersebut dapat dijadikan Standard Operating Procedure (SOP) yang standard dan mudah diikuti oleh kesemua pihak. Meskipun begitu, setakat ini hanya terdapat tiga buah negeri sahaja yang telahpun mengadakan Kaedah atau Peraturan seumpama ini di negeri masing-masing; iaitu Wilayah Persekutuan, Selangor dan Pulau Pinang. ${ }^{32}$

\section{SARANAN DAN PENUTUP}

Peruntukan undang-undang pemelukan Islam dalam Undang-Undang Pentadbiran Agama Islam Negeri yang telah sedia ada di Malaysia adalah belum mencukupi sehinggalah suatu kaedah yang jelas mengenai proses pengislaman, pendidikan, penjagaan kebajikan digubal untuk memperincikan satu persatu proses tersebut. Meskipun perbezaan dan ketidakseragaman yang wujud dalam peruntukan-peruntukan antara negeri tersebut, ianya adalah lambang keunikan dan bagi meraikan kepelbagaian situasi semasa di negeri berkenaan. Namun melalui analisis yang telah dibuat, wujudnya suatu peruntukan yang lengkap dan menyeluruh dapat menjadi asas yang penting bagi menguruskan mualaf di setiap negeri. Selain mengisi kelompangan perundangan yang terdapat pada statut induk, khususnya terhadap empat

32 Kaedah-Kaedah Pentadbiran Undang-Undang Islam (Wilayah-Wilayah Persekutuan) (Cara Pendaftaran, Jagaan dan Pengajaran Mualaf) 2013; PeraturanPeraturan Penjagaan dan Pengajaran bagi Muallaf (Negeri Selangor) 2009; Kaedah Cara Pendaftaran, Jagaan dan Pengajaran Orang Masuk Islam (Negeri Pulau Pinan) 1999. 
elemen yang telah dianalisis, Kaedah atau Peraturan lanjutan juga haruslah digubal di semua negeri bagi memperincikan urusan teknikal pengurusan pendaftaran, penjagaan dan pengajaran mualaf dalam setiap aspek. Dengan adanya peruntukan undang-undang yang lebih komprehensif dan berkesan, hal ini secara tidak langsung dapat menyelesaikan permasalahan dan isu-isu yang melanda golongan mualaf di samping dapat memartabatkan reputasi institusi agama Islam di Malaysia.

\section{RUJUKAN}

Berita Semasa, '(Eksklusif) Laporan Penuh JAIS Berhubung Serbuan Gereja,' laman sesawang Berita Semasa, http://www.beritasemasa.com.my/isugereja-murtad, 4 Ogos 2011.

Blog MIK, 'Isu Serbu Gereja! Ada Mualaf Miskin Terima Bantuan dari NGO Bukan Islam,' laman sesawang Blog $M I K$, http://medan-info-kita. blogspot.my/2011/08/isu-serbu-gereja-ada-mualaf-miskin.html, 8 Ogos 2011 .

Hairol Anuar Mak Din, et al, Kenegaraan Malaysia (Selangor: Penerbitan Imtiazul Ilmi Sdn. Bhd, 2011).

Ikhwan Ng, 'Malaysia Reverted Muslim Statistic,' laman sesawang lifemualaf, http://lifemualaf.blogspot.my/2013/07/malaysia-reverted-muslimstatistic.html, 24 Julai 2013.

MalaysiaKini, 'Revathi: That's My Name, Forever,' laman sesawang MalaysiaKini, http://www.malaysiakini.com/news/69818, 11 Julai 2007.

Mohd Ridhuan Tee Abdullah, Cabaran Saudara Baru di Malaysia (Kuala Lumpur: Utusan Publications \& Distributors Sdn Bhd, 2012).

Norain Saleh, 'Mufti: Ramai Mualaf Yang Pohon Murtad,' laman sesawang MalaysiaKini, www.malaysiakini.com/news/167179, 17 Jun 2011.

Sinar Harian, 'Mualaf Hilang Sumber Pendapatan,' laman sesawang Sinar Harian, http://www.sinarharian.com.my/edisi/johor/mualaf-hilang-sum ber-pendapatan-1.492782, 4 Mac 2016.

Jabatan Kehakiman Syariah Malaysia, 'Rujukan Undang-Undang Syariah,' laman sesawang Portal E-Syariah, www.esyariah.gov.my, 2011.

Jasni Sulong, 'Hak Saudara Baru terhadap Harta Pusaka: Analisis UndangUndang Semasa,' Jurnal Islam dan Masyarakat Kontemporari, vol. 8 (2014). 
Pg Ismail Pg Musa dan Siti Zubaidah Ismail, 'Permohonan Keluar Islam: Kajian Kes di Mahkamah Tinggi Syariah Negeri Sabah,' Jurnal Syariah, vol. 23/1 (2015).

Tun Mohd, Salleh Abbas, Prinsip Perlembagaan dan Pemerintahan di Malaysia (Kuala Lumpur: Dewan Bahasa dan Pustaka, cet. 3, 2006).

\section{Statut}

Akta Pentadbiran Undang2 Islam (Wilayah2 Persekutuan) 1993 (Akta 505/93).

Enakmen Pentadbiran Agama Islam (Negeri Selangor) 2003 (En. 1/03).

Enakmen Pentadbiran Agama Islam (Negeri Sembilan) 2003 (En. 10/03).

Enakmen Pentadbiran Agama Islam (Negeri Melaka) 2002 (En. 7/02).

Enakmen Pentadbiran Agama Islam (Negeri Johor) 2003 (En. 16/03).

Enakmen Pentadbiran Agama Islam (Perak) 2004 (En. 4/04).

Enakmen Pentadbiran Agama Islam (Negeri Pulau Pinang) 2004 (En. 4/04).

Enakmen Pentadbiran Undang2 Islam (Kedah Darul Aman) 2008 (En. 5/08).

Enakmen Pentadbiran Agama Islam 2006, Perlis (En. 4/06).

Enakmen Pentadbiran Undang2 Islam 1991, Pahang (En. 3/91).

Enakmen Pentadbiran Hal Ehwal Agama Islam (Terengganu) (En. 2/01).

Enakmen Majlis Agama Islam Dan Adat Istiadat Melayu Kelantan 1994 (En. 4/94).

Enakmen Pentadbiran Undang2 Islam 1992, Sabah (En. 13/92).

Ordinan Majlis Islam Sarawak, 2001 (Ord. 41/01).

Perlembagaan Persekutuan. 